\title{
MRI in advanced neuromyelitis optica
}

Mitchell S.V. Elkind,

MD, MS

Sherri A. Braksick, MD Jeremy K. Cutsforth-

Gregory, MD

David F. Black, MD

Brian G. Weinshenker, MD

Sean J. Pittock, MD

Orhun H. Kantarci, MD

Correspondence to

Dr. Braksick:

braksick.sherri@mayo.edu

\section{Figure MRI in severe neuromyelitis optica}

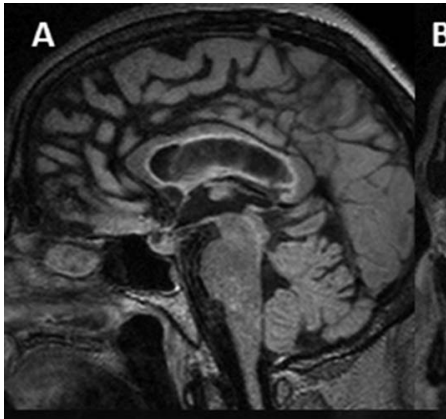

B

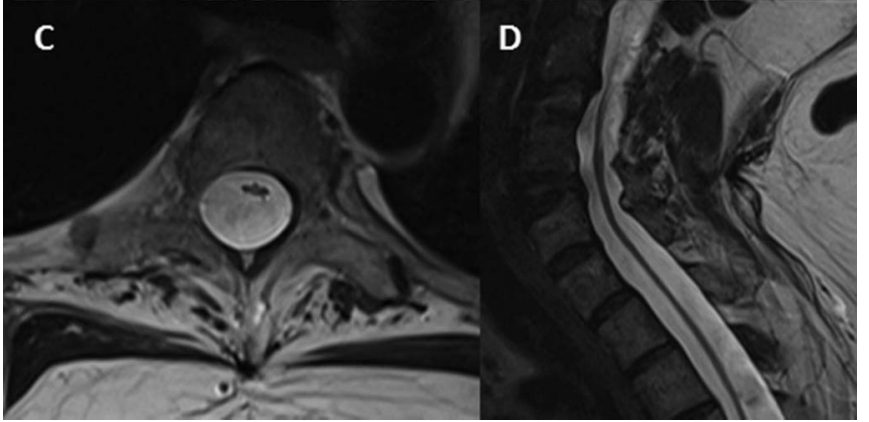

(A) Sagittal T2 fluid-attenuated inversion recovery demonstrates hyperintensity on the internal surface of the corpus callosum surrounding the lateral ventricles and lining the tectum and tegmentum at the level of the cerebral aqueduct. (B) T2 hyperintense lesions perpendicular to the lateral ventricles (Dawson fingers) mimic multiple sclerosis and may lead to misdiagnosis of neuromyelitis optica. (C, D) Severe spinal cord atrophy on T2 imaging.

A 51-year-old woman was treated with multiple medications for relapsing-remitting multiple sclerosis (MS) over 20 years, including interferons and glatiramer, but continued to have recurrent attacks of optic neuritis and transverse myelitis, leading to bilateral blindness and triplegia. Even with MS-type lesions on MRI, neuromyelitis optica (NMO) was ultimately suspected and confirmed by detection of aquaporin- 4 autoantibodies. MRI showed nonenhancing T2 linear hyperintensity around the ventricular system in areas known to highly express aquaporin- 4 (figure). ${ }^{1}$ Profound spinal cord atrophy was evident, consistent with severe, chronic NMO. This case illustrates the lack of effectiveness and potential detriment when MS-directed immunomodulatory medications are aimed at NMO. ${ }^{2}$

\section{AUTHOR CONTRIBUTIONS}

Drs. Braksick and Cutsforth-Gregory were responsible for the initial drafting of the manuscript. Dr. Black assisted in revision of the manuscript and selection of radiographic images. Drs. Weinshenker, Pittock, and Kantarci assisted in revision of the manuscript.

\section{STUDY FUNDING}

No targeted funding reported.

\section{DISCLOSURE}

S. Braksick reports no disclosures relevant to the manuscript. J. Cutsforth-Gregory is a member of the Neurology ${ }^{\circledR}$ Resident \& Fellow Section editorial team. D. Black reports no disclosures relevant to the manuscript. B. Weinshenker serves on data safety monitoring boards for Novartis, Biogen Idec, and Mitsubishi Pharmaceutical Companies; has received payment for consultation from Elan Pharmaceuticals, Asahi Kasei Kuraray Medical Co., Ltd., GlaxoSmithKline Pharmaceuticals, Ono Pharmaceuticals, and CHORD Pharmaceuticals; and serves on the editorial boards of the Canadian Journal of Neurological Sciences, the Turkish Journal of Neurology, and Multiple Sclerosis Journal. He has received research support from the Guthy-Jackson Charitable Foundation and receives license royalties from RSR Ltd. for a patent regarding AQP4-associated antibodies for diagnosis of neuromyelitis optica.

Download teaching slides: Neurology.org

From the Departments of Neurology (S.A.B., J.K.C.-G., B.G.W., S.J.P., O.H.K.) and Radiology (D.F.B.), Mayo Clinic, Rochester, MN. 
S. Pittock and O. Kantarci report no disclosures relevant to the manuscript. Go to Neurology.org for full disclosures.

\section{REFERENCES}

1. Pittock SJ, Weinshenker BG, Lucchinetti CF, Wingerchuk DM, Corboy JR, Lennon VA. Neuro- myelitis optica brain lesions localized at sites of high aquaporin 4 expression. Arch Neurol 2006;63:964968.

2. Kim S, Kim W, Li XF, Jung I, Kim HJ. Does interferon beta treatment exacerbate neuromyelitis optica spectrum disorder? Mult Scler 2012;18:1480-1483. 


\section{Neurology}

Teaching NeuroImages: MRI in advanced neuromyelitis optica

Sherri A. Braksick, Jeremy K. Cutsforth-Gregory, David F. Black, et al.

Neurology 2014;82; e101-e102

DOI 10.1212/WNL.0000000000000246

This information is current as of March 24, 2014

\section{Updated Information \&} Services

\section{Supplementary Material}

\section{References}

Subspecialty Collections

Permissions \& Licensing

\section{Reprints}

including high resolution figures, can be found at: http://n.neurology.org/content/82/12/e101.full

Supplementary material can be found at: http://n.neurology.org/content/suppl/2014/03/22/82.12.e101.DC1

This article cites 2 articles, 0 of which you can access for free at: http://n.neurology.org/content/82/12/e101.full\#ref-list-1

This article, along with others on similar topics, appears in the following collection(s):

All Demyelinating disease (CNS)

http://n.neurology.org/cgi/collection/all_demyelinating_disease_cns Devic's syndrome

http://n.neurology.org/cgi/collection/devics_syndrome

MRI

http://n.neurology.org/cgi/collection/mri

Multiple sclerosis

http://n.neurology.org/cgi/collection/multiple_sclerosis

Information about reproducing this article in parts (figures,tables) or in its entirety can be found online at:

http://www.neurology.org/about/about_the_journal\#permissions

Information about ordering reprints can be found online:

http://n.neurology.org/subscribers/advertise

Neurology ${ }^{\circledR}$ is the official journal of the American Academy of Neurology. Published continuously since 1951, it is now a weekly with 48 issues per year. Copyright (C) 2014 American Academy of Neurology. All rights reserved. Print ISSN: 0028-3878. Online ISSN: 1526-632X.

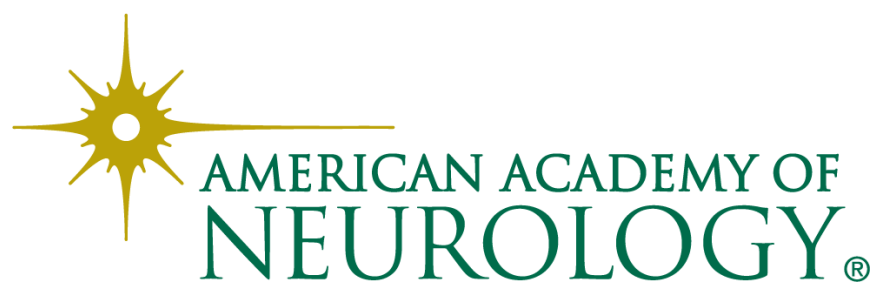

